\title{
Mapping of AFLP loci linked to tolerance to cowpea golden mosaic virus
}

\author{
M.A. Rodrigues ${ }^{1}$, C.A.F. Santos ${ }^{2}$ and J.R.F. Santana ${ }^{1}$ \\ ${ }^{1}$ Departamento de Ciências Biológicas, \\ Universidade Estadual de Feira de Santana, Feira de Santana, BA, Brasil \\ ${ }^{2}$ Embrapa Tropical Semiárido, Petrolina, PE, Brasil \\ Corresponding author: C.A.F. Santos \\ E-mail: casantos@cpatsa.embrapa.br
}

Genet. Mol. Res. 11 (4): 3789-3797 (2012)

Received November 8, 2011

Accepted March 5, 2012

Published August 17, 2012

DOI http://dx.doi.org/10.4238/2012.August.17.12

\begin{abstract}
AFLP markers combined with the bulk segregant analysis methodology was used for the identification of molecular markers associated with the cowpea golden mosaic virus (CGMV) resistance gene in $286 \mathrm{~F}_{2}$ cowpea plants derived from the cross IT97K-499-35 x Canapu T16. Segregation data in the $F_{2}$ population demonstrated that tolerance to CGMV is controlled by a single dominant gene. Among the 196 combinations of AFLP primers tested, which generated approximately 3800 amplicons, three markers linked to the CGMV resistance gene were identified: E.AAC/M.CCC ${ }_{515}$ at $4.3 \mathrm{cM}$, E.AGG/M.CTT 280 at $14.2 \mathrm{cM}$ and E.AAA/M.CAG ${ }_{352}$ at $16.8 \mathrm{cM}$, with 50.4, 24.4, and 28.7 LOD scores, respectively; the former two markers flank the CGMV loci. These markers could be used for the development of 'sequence characterized amplified region' type markers or for greater saturation of this region, to increase the precision of assisted selection for the development of cowpea strains tolerant to CGMV.
\end{abstract}

Key words: Vigna unguiculata; Bulk segregant analysis; Genetic mapping 


\section{INTRODUCTION}

Cowpea (Vigna unguiculata [L.] Walp.) is one of the principal crops of northeastern Brazil and is considered a source of income and basic food for its population (Oliveira et al., 2002). The crop is attacked by various pathogenic agents that reduce quality and grain yield (Sobrinho Athayde et al., 2000). Of these, the infections caused by viruses stand out because they can reduce production from 60 to $80 \%$ in more susceptible cultivars, predominantly the traditionally cultivated varieties. More than 20 viruses that naturally infect this crop have been reported (Thottappilly and Rossel, 1985). Among them, the cowpea golden mosaic virus (CGMV) stands out for causing excessive losses of 40 to $78 \%$ production (Santos and Freire-Filho, 1984).

Resistance to CGMV has been attributed to 2 dominant and independent genes by Sangwan and Rishi (2004), who worked with $\mathrm{F}_{1}$ and $\mathrm{F}_{2}$ populations and backcrosses of 2 resistant cultivars, CS 39 and CS 55, and 2 susceptible ones, GC 2 and HFC 42-1. Another study has indicated that resistance to the golden mosaic virus is controlled by a dominant gene (Kumar et al., 1994). In Phaseolus vulgaris, resistance to the golden mosaic virus has been attributed to 3 genes: a dominant gene that controls the reaction to dwarfism and 2 unlinked recessive genes responsible for resistance to chlorosis (Valez et al., 1998).

The use of molecular markers has contributed greatly to the development of genetic linkage maps for several plant species of economic interest, including V. unguiculata. Amplified fragment length polymorphism (AFLP) markers (Vos et al., 1995) have been used widely in the construction of genetic maps in cowpea (Menéndez et al., 1997; Quédraogo et al., 2001, 2002; Boukar et al., 2004). Owing to the unlimited number of polymorphisms that can be analyzed using the AFLP technique, specific regions of the genome can be saturated, a prerequisite for cloning based on target gene maps (Borém and Caixeta, 2009).

AFLP markers, combined with the bulk segregant analysis (BSA) methodology (Michelmore et al., 1991), have been used with success in the identification of molecular markers linked with genes of agronomic importance, such as those conferring resistance genes to pests and diseases. Quédraogo et al. (2001) have adopted AFLP and BSA methodologies to identify markers closely linked to 2 genes that confer resistance to 2 races of the pest Striga gesnerioides Willd. Other studies aimed at the application of molecular markers in the identification of resistance genes to several diseases caused by viruses have been carried out in plant species such as green pea (Pisum sativum L.) (Gao et al., 2004) and common bean (P. vulgaris L.) (Kelly et al., 2003).

Blair et al. (2007) have developed a sequence characterized amplified region (SCAR) marker, which was found at $7.8 \mathrm{cM}$ from the gene $b g m-1$, which confers resistance to the golden mosaic virus in P. vulgaris. No studies on the mapping of resistant genes to the CGMV have yet been reported. The objective of the present study was to identify AFLP molecular markers linked to genes resistant genes to CGMV in an $\mathrm{F}_{2}$ population derived from an IT97K-499-35 x Canapu T16 cross to facilitate the development of SCAR markers for assisted selection in the development of cultivars resistant to CGMV.

\section{MATERIAL AND METHODS}

\section{Genetic material and cross}

Two hundred and eighty-six $\mathrm{F}_{2}$ plants from a cross between genotypes IT97K-499-35 
and Canapu T16 were analyzed. IT97K-499-35 is a black-eyed cultivar developed by the International Institute of Tropical Agriculture. This cultivar presents multiple tolerances to several viruses, including CGMV (Singh et al., 2006). Canapu T16 belongs to the canapu group, a type largely grown in a region of the Vale do São Francisco that is susceptible to CGMV.

The cross was performed as described by Rachie et al. (1975). After planting the seeds that resulted from the crosses, the success of the hybridization using the seed coat phenotypic marker was observed: all of the $\mathrm{F}_{1}$ seeds presented a black seed coat in contrast with the blackeyed pea type of the parental IT 97K-499-35 and the brown of the other parent.

\section{Evaluation of CGMV resistance in the $F_{2}$ population}

$\mathrm{F}_{1}$ seeds from the cross IT97K-499-35 x Canapu T16 were planted in the experimental field of Embrapa Tropical Semiárido between 2 borders of Canapu, the variety susceptible to CGMV, which were planted 30 days earlier to increase the population of Bemisia tabaci, a vector of CGMV, and reduce the chances of escape. Normal cultural practices were adopted, but no insecticides were applied to avoid interference with the population of the insect vector. Plants that presented the typical symptoms of CGMV infection - golden yellow coloration on the leaf surface - were considered susceptible, whereas healthy plants that displayed no symptoms were considered resistant.

\section{Extraction of genomic DNA and AFLP reactions}

Young leaves of offspring from the cross IT97K-499-35 x Canapu T16 were collected, properly identified, and stored in a freezer at $-80^{\circ} \mathrm{C}$. The cetyltrimethylammonium bromide 2X protocol of Doyle and Doyle (1990) was used for the extraction of genomic DNA with the following modifications: 6000 and 10,000 rpm in the first and second centrifugations, respectively, and $\beta$-mercaptoethanol at $2 \%$ and incubation at $60^{\circ} \mathrm{C}$ for $30 \mathrm{~min}$ for all of the samples. After the addition of Tris-ethylenediaminetetraacetic acid buffer, the DNA solution was treated with RNAse to remove co-isolated RNAs. The quantification of the DNA extracted was performed through visual comparison of the intensity of its bands with those obtained from phage $\lambda$ DNA (10 to $100 \mathrm{ng}$ ) on $0.8 \%(\mathrm{w} / \mathrm{v})$ agar gel stained with ethidium bromide. The samples were diluted to $50 \mathrm{ng} / \mu \mathrm{L}$ based on the estimated concentrations and stored at $-20^{\circ} \mathrm{C}$.

The methodology described by Vos et al. (1995) was used in the analysis of the AFLP markers. Initially, the genomic DNA was doubly digested with 2 restriction enzymes. For this, 200 ng DNA was doubly digested with $0.62 \mathrm{U}$ of each endonuclease for $2.5 \mathrm{~h}$ in a thermocycler with the combinations between the restriction enzymes EcoRI/MseI and PstI/ MseI.

The programming of the thermocycler for pre-selective amplifications consisted of 20 cycles at $94^{\circ} \mathrm{C}$ for $30 \mathrm{~s}, 56^{\circ} \mathrm{C}$ for $1 \mathrm{~min}$, and $72^{\circ} \mathrm{C}$ for $1 \mathrm{~min}$. Each pre-amplified reaction was diluted 20 times in ultrapure water. In the selective PCRs, 100 pairs of initiators EcoRI + MseI and 96 pairs of initiators Pst + MseI were used. The reactions were prepared for a final volume of $10 \mu \mathrm{L}$ according to these concentrations: $0.2 \mu \mathrm{M}$ EcoRI or Pst I primer, $0.3 \mu \mathrm{M}$ MseI primer, $0.2 \mathrm{mM}$ deoxyribonucleotide triphosphates, $1 \mathrm{X}$ PCR buffer, $2.5 \mathrm{mM}$ $\mathrm{MgCl}_{2}, 0.5 \mathrm{U}$ Taq DNA polymerase, and $2.0 \mu \mathrm{L}$ pre-amplified and diluted DNA. The pro- 
gramming of the thermocycler for the selective amplifications consisted of 2 steps: 1) a cycle at of $94^{\circ} \mathrm{C}$ for $30 \mathrm{~s}$ followed by 13 repetitions of $65^{\circ} \mathrm{C}$ for $30 \mathrm{~s}$ and of $72^{\circ} \mathrm{C}$ for $60 \mathrm{~s}$, and an annealing temperature of $65^{\circ} \mathrm{C}$ diminishing $0.7^{\circ} \mathrm{C}$ in each subsequent cycle, and 2) 23 cycles at $94^{\circ} \mathrm{C}$ for $30 \mathrm{~s}, 56^{\circ} \mathrm{C}$ for $30 \mathrm{~s}$, and $72^{\circ} \mathrm{C}$ for $1 \mathrm{~min}$.

The amplification products were separated on $6 \%$ polyacrylamide gel (acrylamide:bisacrylamide [19:1], 7.5 M urea, and 5X Tris/borate/EDTA buffer). The electrophoresis ran for approximately $3 \mathrm{~h}$ with a constant power of $40 \mathrm{~W}$. The gels were stained with silver nitrate according to the procedure described by Creste et al. (2001).

\section{Identification of AFLP markers associated with resistance loci}

For BSA (Michelmore et al., 1991), 2 duplicate groups were created: one composed of CGMV-resistant plants and the other of CGMV-susceptible plant. Each group contained DNA from 5 individuals. Equimolar quantities of the DNA of these individuals were used for the preparation of 2 susceptible bulks and 2 resistant bulks (Figure 1). The primers that amplified candidate fragments - present in the susceptible bulk and absent in the resistant bulk and vice versa - were again evaluated in the sample of the 5 resistant and susceptible individuals and in a larger sample comprising 35 tolerant and 15 susceptible individuals (Figure 2). Only the primers that segregated close to the proportion of $3: 1$ were selected to phenotype the $286 \mathrm{~F}_{2}$ individuals.

An estimate of the size of each AFLP fragment was made using the method of inverse mobility based on the regression of products of known size of the molecular marker of $50 \mathrm{bp}$ (Fermentas, USA), applied in an extra well of the polyacrylamide gel.

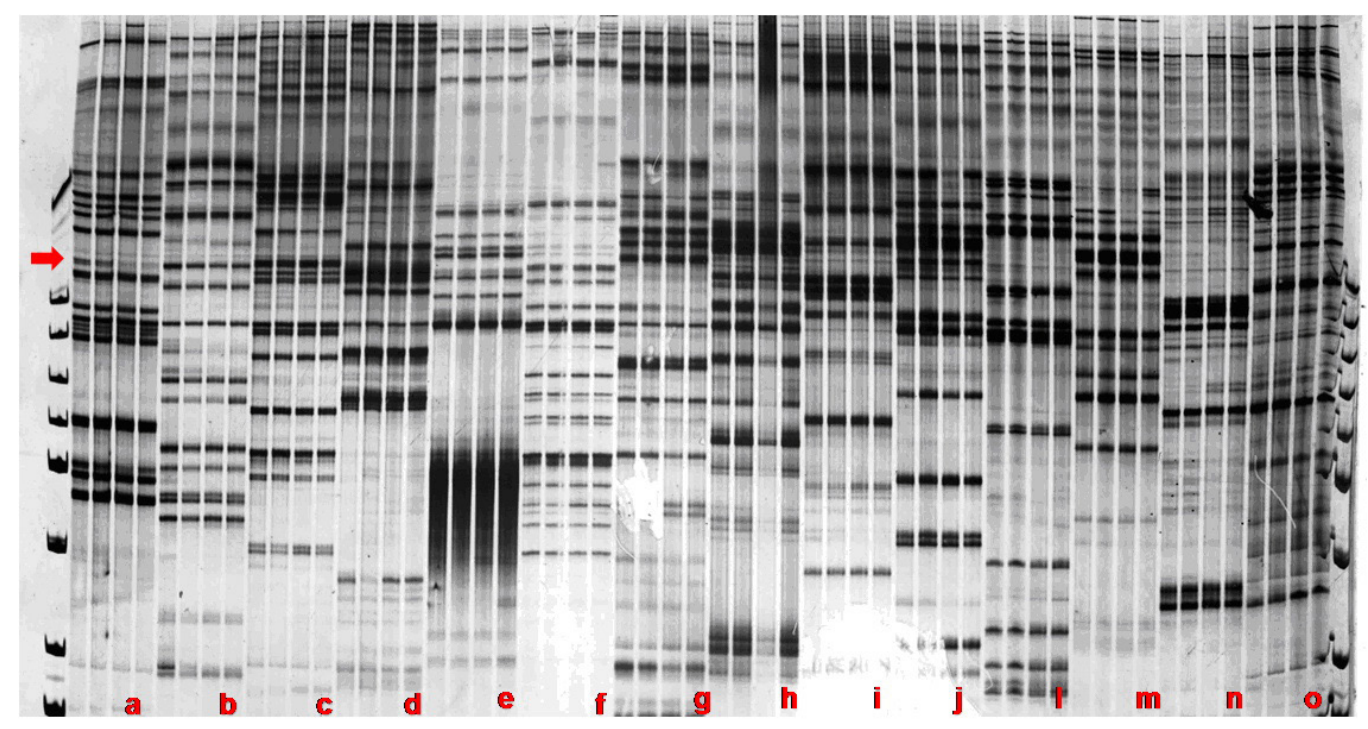

Figure 1. Polyacrylamide gel demonstrating 14 bulks of resistant and susceptible individuals (represented by the letters 'a' to 'o'), in duplicate with two resistant bulks and two susceptible ones, respectively. One polymorphism among the bulks was indicated by an arrow. 


\section{Statistical analysis}

The data obtained using the AFLP markers and through visual evaluation of resistance/susceptibility were submitted to the chi-square test for verification of the Mendelian pattern of segregation of $3: 1$ expected in the $\mathrm{F}_{2}$ population. The linkage analyses were performed using JoinMap version 2.0 (Stam and van Ooijen, 1995). The minimum logarithm (base 10) of odds (LOD) of 3.0, the maximum recombination frequency of 0.45 , the "jump" limit of 3.0, and the "triplet" limit of 3.0 were adopted. The values obtained for the recombination frequencies were converted to genetic distance maps (centimorgans) using the Kosambi (1943) function for illustration in a diagram.

\section{RESULTS}

The visual identification of susceptible and resistant plants was easy to make, because the characteristic symptoms of CGMV are golden-yellow spots that contrast in the field. In the 286 plants evaluated in the $\mathrm{F}_{2}$ population of the IT97K-499-35 x Canapu T16 cross, resistance was verified in 223 plants, whereas 63 showed susceptibility to CGMV.

The results obtained were submitted to the chi-square test that showed no significant result at the 5\% level (1.35), which validated the Mendelian segregation of 3:1 (resistant:susceptible). These data suggest a segregation of 3:1, with dominance of the gene that confers resistance to the disease.

Of the 100 pairs of EcoRI/MseI initiators and 96 pairs of PstI/MseI initiators tested in the bulks of resistant and susceptible individuals of the cross IT97K-499-35 x Canapu T16, 3768 bands were amplified, with 2022 being the combination EcoRI/Mse and 1746 PstI/MseI. Thirty polymorphic bands were identified among the resistant/susceptible bulks, with 22 being in the pairs of initiators $E c o \mathrm{RI} / \mathrm{MseI}$ and 8 in the pairs of primers PstI/MseI. Of the combinations of primers that showed polymorphism among the bulks, only 3 were consistent when they were analyzed in 35 resistant individuals and 15 susceptible ones, confirming the result of the initial evaluation with the resistant and susceptible bulks (see Figure 2).

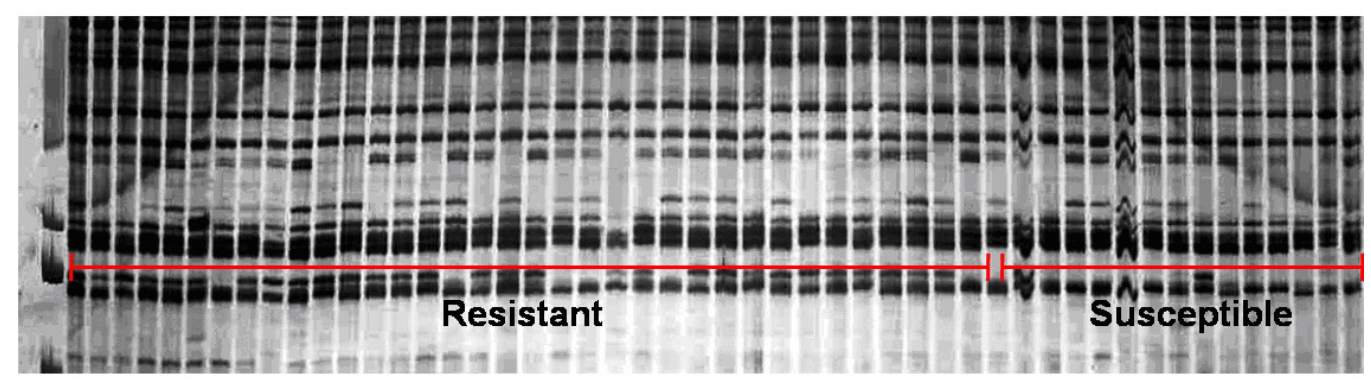

Figure 2. Polyacrylamide gel with 50 individuals. The first 35 individuals are resistant and the last 15 are susceptible to the golden mosaic virus analyzed with the combination E.AAA/M.CAG.

The markers E.AAC/M.CCC, E.AGG/M.CTT, and E.AAA/M.CAG correspond to amplified DNA fragments of 515, 280, and $352 \mathrm{bp}$, respectively. The linkage of these 3 markers with the resistance locus, which was called $M d o-1$, the symbol of the resistance gene, was con- 
firmed in the 286 individuals of the $\mathrm{F}_{2}$ population given that the distances for the locus Mdo-1 varied from 4.3 to $21.1 \mathrm{cM}$.

Recombination analysis estimated that the marker E.AAC/M.CCC ${ }_{515}$ is located $4.3 \mathrm{cM}$ from $M d o-1$, with an LOD score of 50.4, whereas the markers E.AGG/M.CTT ${ }_{280}$ and E.AAA/M. $\mathrm{CAG}_{352}$ are positioned 14.2 and $16.8 \mathrm{cM}$ away with LOD scores of 24.4 and 28.7 and markers E.AAC/M.CCC ${ }_{515}$ and E.AAA/M.CAG ${ }_{452}$, respectively, are flanking (Figure 3).

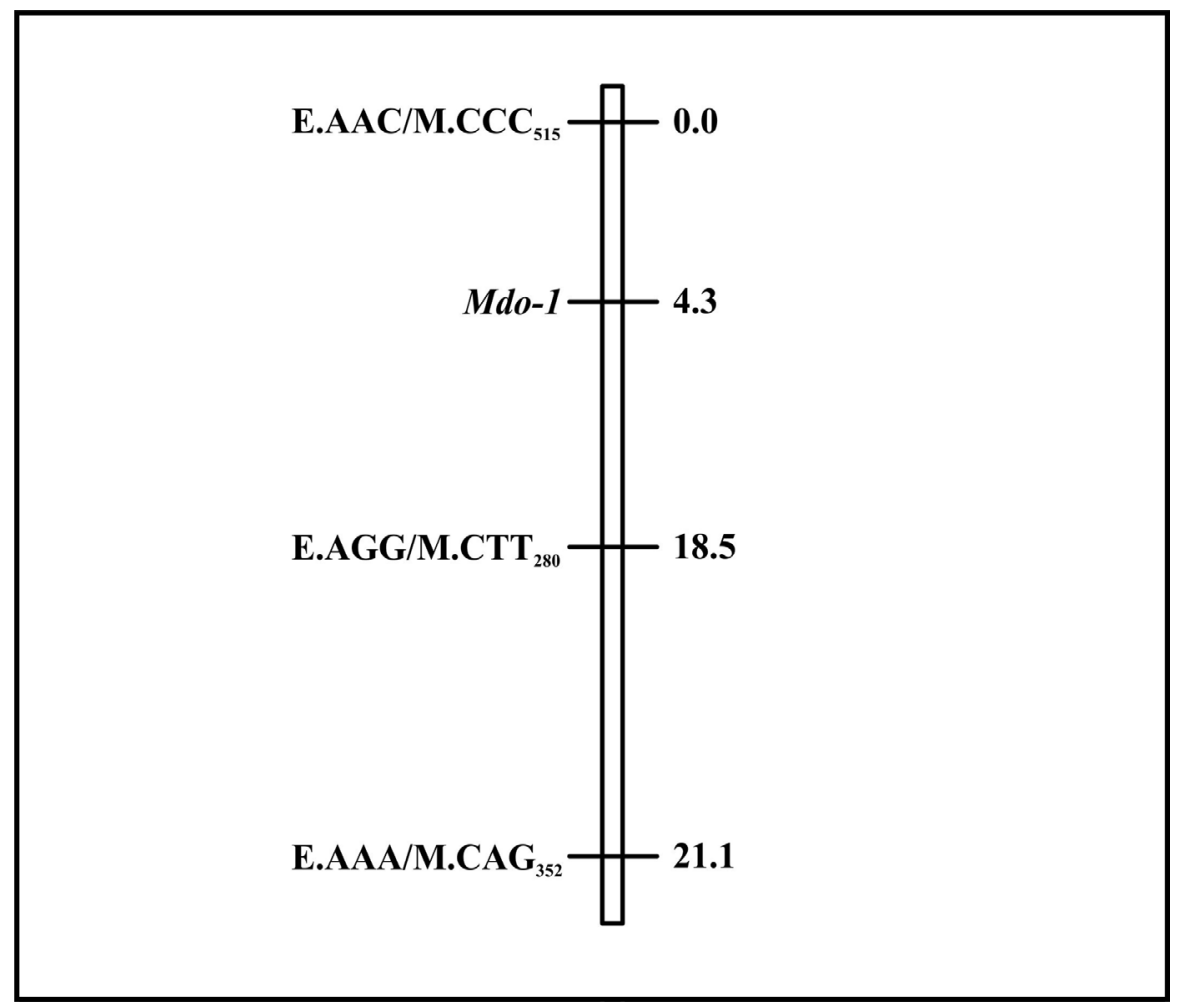

Figure 3. Linkage map of the resistance locus for golden mosaic $(M d o-1)$ with the positions of the amplified fragment length polymorphism markers identified and their respective distances (cM). Logarithm of the odds scores of 50.4, 24.4, and 28.7, respectively, for the markers E.AAC/M.CCC ${ }_{515}$, E.AGG/M.CTT 280 and E.AAA/M.CAG 352.

The study of genetic inheritance performed in the segregating $F_{2}$ population for CGMV indicates that resistance to the disease is controlled by a dominant gene segregating in the proportion of 3:1 (resistant:susceptible). The results obtained differ from those reported by Sangwan and Rishi (2004), in which resistance to CGMV was attributed to 2 dominant genes segregating in the proportion of 15:1 in $\mathrm{F}_{2}$ plants and 3:1 in backcrosses, indicating that resistance is conditioned by 2 dominant and independent genes. The authors cite 2 studies, in which resistance is attributed to only 1 gene (Bliss and Robertson, 1971; Kumar et al., 1994). Conversely, in the common bean (P. vulgaris L.), resistance to golden mosaic is conferred by 2 unlinked recessive genes (Valez and Bassett, 1998). Studies evaluating the segregating populations of backcrosses of these progenitors will be necessary to confirm the genetic inheritance to golden mosaic virus. 


\section{DISCUSSION}

Our results showed that the combination of AFLP markers and the BSA technique was efficient for the localization of markers linked to the resistance gene to CGMV. Despite the fact that the great majority of published researchs in this field have used 8 or more individuals to compose the bulks or groups (Quédraogo et al., 2001; Boukar et al., 2004), our use of only 5 individuals in each bulk did not compromise the results, because 3 markers linked to the resistance gene were identified, as adopted by Boiteux et al. (2000) and Brito (2007) in carrot and coffee, respectively.

The AFLP methodology has also been used satisfactorily in other studies with cowpea: in the identification of molecular markers linked to resistance genes to diseases and pests (Menéndez et al., 1997; Quédraogo et al., 2001, 2002; Boukar et al., 2004), in phenetic analyses and analyses of genetic diversity (Coulibaly et al., 2002), and in the localization of quantitative trait loci (Muchero et al., 2010). The ample use of AFLP markers in molecular analyses, especially in the genetic mapping of cowpea, demonstrates its efficiency in identifying loci linked to segregating characteristics of commercial interest. Despite its generation of dominant marks - in other words, being unable to distinguish heterozygote loci - the technique has become an important tool in the genetic improvement of cowpea as well as other species of the genus Vigna.

The combinations of the rare and frequent restriction enzymes EcoRI/MseI and PstI/ MseI amplified 20.2 and 18.2 bands, respectively. These values are inferior to those found by Menéndez et al. (1997), who in analyzing a cross between 2 genotypes of $V$. unguiculata (IT84S-2049 x 524) developed in Nigeria and California and contrasting for several morphological traits and resistance to pests and diseases found an average of approximately 55 fragments/primer and $12 \%$ polymorphism per combination of AFLP primer using a fluorescent system and semi-automatic sequencer. Oliveira et al. (2001) obtained an average of 7.6 amplified bands using random amplification of polymorphic DNA markers in the genetic mapping and the selection of hybrids between Citrus reticulata Blanco and Citrus sinensis (L.) Osbeck. Boiteux et al. (2000) have reported an average of 2.4 amplicons of random amplification of polymorphic DNA in the mapping of a nematode in an $\mathrm{F}_{2}$ population of carrot.

The enzymes EcoRI/MseI produced a superior number of total amplified fragments and polymorphic fragments between the segregating bulks: 53.6 and $73.3 \%$, respectively. These values demonstrate that the combination EcoRI/MseI was more efficient than PstI/MseI in detecting polymorphic loci and was similar to those reported by Campos et al. (2005), in which the combinations of enzymes EcoRI/MseI produced greater numbers of bands and polymorphisms than did the combinations $P s t \mathrm{I} / M s e \mathrm{I}$ in a study of genetic diversity among cultivars of Citrus ssp. The quantity of AFLP markers identified in this study is close to that obtained by Boukar et al. (2004), who identified 4 AFLP markers linked to the resistance gene to $S$. gesnerioides with genetic distances of approximately 3.2 (E.ACT/M.CTC ${ }_{115}$ ), 4.8 $\left(\right.$ E.ACT/M.CAC 115 ), 10.3 (E.ACA/M.CAG 108 ), and $18.2 \mathrm{cM}\left(\mathrm{E} . \mathrm{AAG} / \mathrm{M} \mathrm{CTA}{ }_{190}\right)$. The marker E-ACT/M-CAC ${ }_{115}$ was sequenced and converted to an SCAR, and when tested in the $\mathrm{F}_{2}$ population, was efficient in distinguishing susceptible and resistant individuals.

Quédraogo et al. (2002) have used AFLP markers to develop a linkage map that serves as a reference owing to its high density and ample coverage of the $V$. unguiculata genome. In this study, several markers linked to disease resistance genes were identified, including cow- 
pea mosaic virus (CPMV), cowpea severe mosaic virus (CpSMV), Black-eyed cowpea mosaic virus, and Southern bean mosaic virus. Souframanien and Gopalakrishna (2006) have applied the inter-simple sequence repeat technique to identify the marker ISSR811 ${ }_{1357}$, located at 6.8 $\mathrm{cM}$ from the resistance gene to the mung bean yellow mosaic virus in $\mathrm{F}_{8}$ recombinant strains of genotypes of mung beans (Vigna mungo [L.] Hepper). ISSR $811_{1357}$ was converted with success in an SCAR and was capable of distinguishing susceptible and resistant plants to the mung bean yellow mosaic virus in agreement with the phenotypic data.

In the present study, 3 markers linked to the resistance gene to CGMV were identified, with 2 markers flanking the resistance gene to the mosaic (E.AAC/M.CCC $515.3 \mathrm{cM}$ away and E.AGG/M.CTT ${ }_{280} 14.2 \mathrm{cM}$ away). Before this study, no marker linked to the resistance gene for CGMV had been identified, making this linkage map the first in a population of $V$. unguiculata segregated for resistance to the CGMV.

The marker E.AAC/M.CCC ${ }_{515}$ obtained in the present study appears to be a strong candidate for use in assisted selection by molecular markers given its greater proximity to the resistance gene. It is also a strong candidate to be converted into an SCAR marker, which is superior to an AFLP marker. SCAR markers for genes that confer resistance to CGMV may assist breeding programs, increasing the accuracy of assisted selection for the development of CGMV-tolerant strains.

\section{ACKNOWLEDGMENTS}

Research supported by Banco do Nordeste do Brasil (FUNDECI) and Fundação de Amparo à Pesquisa do Estado da Bahia (FAPESB).

\section{REFERENCES}

Blair MW, Rodriguez LM, Pedraza F, Morales F, et al. (2007). Genetic mapping of the bean golden yellow mosaic geminivirus resistance gene bgm-1 and linkage with potyvirus resistance in common bean (Phaseolus vulgaris L.). Theor. Appl. Genet. 114: 261-271.

Bliss FA and Robertson DG (1971). Genetics of host reaction in cowpea to cowpea yellow mosaic virus and cowpea mottle virus. Crop Sci. 11: 258-262.

Boiteux SL, Belter GJ, Roberts AP and Simon WP (2000). RAPD linkage map of the genomic region encompassing the root-knot nematode (Meloidogyne javanica) resistance locus in carrot. Theor. Appl. Genet. 100: 439-446.

Borém A and Caixeta ET (2009). Marcadores Moleculares. Editora UFV, Viçosa.

Boukar O, Kong L, Singh BB, Murdock L, et al. (2004). AFLP and AFLP-Derived SCAR markers associated with Striga gesnerioides resistence in cowpea. Crop Sci. 44: 1259-1264.

Brito de GG (2007). Mapeamento Genético de Marcadores AFLP Ligados ao Gene de Resistência do Cafeeiro à Hemileila vastatrix Berk. \& Br. Doctoral thesis, Universidade Federal de Viçosa, Viçosa.

Campos TE, Espinosa MAG, Warburton ML, Varela AS, et al. (2005). Characterization of mandarin (Citrus spp.) using morphological and AFLP markers. Interciencia 30: 687-693.

Coulibaly S, Pasquet RS, Papa R and Gepts P (2002). AFLP analysis of the phenetic organization and genetic diversity of Vigna unguiculata L. Walp. Reveals extensive gene flow between wild and domesticated types. Theor. Appl. Genet. 104: 358-366.

Creste S, Neto Tulmann A and Figueira A (2001). Detection of single sequence repeat polymorfisms in denaturing polyacrylamide sequencing gels by silver staining. Plant Mol. Biol. Rep. 19: 299-306.

Doyle JJ and Doyle JL (1990). Isolation of plant DNA from fresh tissue. Focus 12: 13-15.

Gao Z, Eyers S, Thomas C, Ellis N, et al. (2004). Identification of markers tightly linked to sbm recessive genes for resistance to Pea seed-borne mosaic virus. Theor. Appl. Genet. 109: 488-494.

Kelly JD, Gepts P, Miklas PN and Coyne DP (2003). Tagging and mapping of genes and QTL and molecular markerassisted selection for traits of economic importance in bean and cowpea. Field Crop Res. 82: 135-154. 
Kosambi DD (1943). The estimation of map distances from recombination values. Ann. Eug. 12: 172-175.

Kumar K, Dahiya SB and Rish N (1994). Inheritance to Cowpea Yellow Mosaic Virus in Cowpea (Vigna unguiculata (L.) Walp.). In: Virology in the Tropics (Rishi N, Ahuja KL and Singh BP, eds.). Malhotra Publishing House, New Delh.

Menéndez CM, Hall AE and Gepts P (1997). A genetic linkage map of cowpea (Vigna unguiculata) developed from a cross between two inbred, domesticated lines. Theor. Appl. Genet. 95: 1210-1217.

Michelmore RW, Paran I and Kesseli RV (1991). Identification of markers linked to disease-resistance genes by bulked segregant analysis: a rapid method to detect markers in specific genomic regions by using segregating populations. Proc. Natl. Acad. Sci. U. S. A. 88: 9828-9832.

Muchero W, Ehlers JD and Roberts PA (2010). Restriction site polymorphism-based candidate gene mapping for seedling drought tolerance in cowpea [Vigna unguiculata (L.) Walp.]. Theor. Appl. Genet. 120: 509-518.

Oliveira AP, Sobrinho Tavares J, Nascimento JT, Alves AU, et al. (2002). Avaliação de linhagens e cultivares de feijãocaupi, em Areia, PB. Hortic. Bras. 20: 180-182.

Oliveira RP de, Cristofani M and Machado MA (2001). Marcadores RAPD para mapeamento genético e seleção de híbridos de citros. Rev. Bras. Frutic. 23: 477-481.

Quédraogo JT, Maheshwari V, Berner KD, St-Pierre AC, et al. (2001). Identification of AFLP markers linked to resistence os cowpea (Vigna unguiculata L.) to parasitism by Striga gesnerioides. Theor. Appl. Genet. 102: 1029-1036.

Quédraogo JT, Gowda BS, Jean M, Close TJ, et al. (2002). An improved genetic linkage map for cowpea (Vigna unguiculata L.) combining AFLP, RFLP, RAPD, biochemical markers, and biological resistance traits. Genome 45: 175-188.

Rachie KO, Rawal KM and Franckowiak JD (1975). A Rapid Method for Hand Crossing Cowpeas. International Technical Bulletin. International Institute of Tropical Agriculture, Ibadan.

Sangwan SR and Rish N (2004). Genetics of resistance to cowpea yellow mosaic virus in cowpea (Vigna unguiculata (L.) Walp.). Ind. J. Mycol. Plant Pathol. 34: 620-622.

Santos AA dos and Freire-Filho FR (1984). Redução da produção do feijão massacar causado pelo vírus do mosqueado amarelo. Fitopatol. Bras. 9: 407.

Singh BB, Olufajo OO, Ishiyaku MF, Adeleke RA, et al. (2006). Registration of six improved germplasm lines of cowpea with combined resistance to Striga gesnerioides and Alectra vogelii. Crop Sci. 46: 2332-2233.

Sobrinho Athayde C, Viana FMP and Santos AA dos (2000). Doenças do Feijão Caupi. In: A Cultura do Feijão Caupi no Meio-Norte do Brasil (Cardoso MJ, ed.). Embrapa Meio-Norte, Teresina, 264.

Souframanien J and Gopalakrishna T (2006). ISSR and SCAR markers linked to the Mungbean yellow mosaic virus (MYMV) resistence gene in blackgran [Vigna mungo (L.) Hepper]. Plant Breed. 125: 619-622.

Stam P and van Ooijen JW (1995). JOINMAP TM Version 2.0: Software for the Calculation of Genetic Maps. CPRODLO, Wageningen.

Thottappilly G and Rossel HW (1985). Worldwide Ocurrence and Distribution of Virus Diseases. In: Cowpea Research, Production and Utilization (Singh SR and Richaie KO, eds.). John Wiley, Chichester, 155-171.

Valez J, Bassett MJ, Beaver JS and Molina A (1998). Inheritance of resistance to Bean golden mosaic virus in common bean. J. Am. Soc. Hortic. Sci. 123: 628-631.

Vos P, Hogers R, Bleeker M, Reijans M, et al. (1995). AFLP: a new technique for DNA fingerprinting. Nucleic Acids Res. 23: 4407-4414. 